\title{
Expression of CD44 and its variants on gastric epithelial cells of patients with Helicobacter pylori colonisation
}

Xuejun Fan, Aideen Long, Michael Goggins, Xuegong Fan, P W N Keeling, Dermot Kelleher

\begin{abstract}
Background-Studies have suggested that expression of the adhesion molecule CD44 may be of prognostic importance in gastric cancer. In addition, there is strong evidence that Helicobacter pylori has a role in gastric cancer.
\end{abstract}

Aims-To determine the expression of CD44 and its variants (v6, v9) and HLA class II molecules on human gastric epithelial cells and intraepithelial lymphocytes in patients with and without $H$ pylori infection.

Patients-Eighteen patients (seven men and 11 women) attending for endoscopic evaluation because of upper gastrointestinal symptoms were included. An additional 10 patients (five men and five women) were analysed for CD44 variant expression).

Methods-Biopsy specimens were taken from the gastric antrum during endoscopy. Gastric epithelial cells and intraepithelial lymphocytes were examined by two colour flow cytometry and compared in patients with and without $H$ pylori infection.

Results-Expression of CD44 and its variants (CD44 v9) was increased in epithelial cells but not in intraepithelial lymphocytes. Both epithelial cells and intraepithelial lymphocytes expressed higher levels of HLA class II molecules (DR and DP), possibly as a result of local cytokine production. Furthermore, results showed upregulation of CD44 on a gastric epithelial cell line (AGS) by cytokines and peripheral blood mononuclear cell supernatant.

Conclusions-These data suggest that $H$ pylori, either directly or through a local inflammatory response, is responsible for increased expression of CD44 and its variant CD44 v9. These data are of potential importance in relation to increased expression of CD44 and CD44 v9 on gastric carcinoma.

(Gut 1996; 38: 507-512)

Keywords: Helicobacter pylori, adhesion molecules, CD44 and variants (v9, v6), MHC class II, gastric cancer, epithelial cells, intraepithelial lymphocytes, gastric epithelial cell line (AGS).

P W N Keeling

D Kelleher

Correspondence to:

Dr D Kelleher, Departmen of Clinical Medicine, Trinity College Dublin, St James's Hospital, Dublin 8, Ireland

Accepted for publication 23 October 1995

Helicobacter pylori colonises human gastric epithelium and is the commonest cause of antral gastritis and duodenal ulceration. ${ }^{1}$ In addition, there is considerable evidence that $H$ pylori has a role in the aetiology of gastric cancer. ${ }^{2} 3$ This evidence comes from several nested case-control studies and from numerous pathological studies suggesting that the natural history of $H$ pylori infection is that of chronic active gastritis, which may ultimately result in premalignant gastric mucosal atrophy, intestinal metaplasia, and achlorhydria. ${ }^{45}$ In addition, $H$ pylori is almost always found in gastric dysplasia and early gastric cancer. ${ }^{6}$ Several mechanisms have been suggested by which $H$ pylori infection could lead to gastric cancer. Directly and indirectly, by the immune inflammatory response, $H$ pylori can influence the rate of epithelial cell proliferation, suggesting that the bacterium may be an initiating step in gastric carcinogenesis and an important cocarcinogenic factor. ${ }^{78}$

CD44 is a cell surface adhesion molecule ${ }^{910}$ expressed on a wide variety of cell types including epithelial cells. ${ }^{1112} \mathrm{CD} 44$ exists in a number of isoforms as a result of alternate splicing and post-translational modification, varying in molecular weight from $85-90 \mathrm{kDa}$ to $200 \mathrm{kDa} .^{1314}$ CD44 is important in mediating $T$ cell and macrophage adhesion, migration and activation, lymphocyte homing, natural killer cell mediated cytotoxicity, haemopoesis, and metastasis. ${ }^{9} 1015$ Expression of CD44 variant adhesion molecules has been detected on several tumours and its expression may be associated with increased metastatic potential. ${ }^{13}$

Recent data have suggested that inflammatory mediators such as interferon $\gamma$ (IFN- $\gamma$ ) may upregulate expression of CD44. ${ }^{11}$ Furthermore, previous studies have shown that CD44 and CD44 variants are expressed in normal gastric tissue. ${ }^{13}$ Notably, the CD44 variant, CD44 v9 was found to be expressed in gastric carcinoma, a malignancy associated with $H$ pylori infection, ${ }^{45}$ and this expression was of prognostic importance. ${ }^{16-19}$ As there is a strong association between $H$ pylori and gastric carcinoma, we aimed to determine whether $H$ pylori might play a role in the induction of CD44 v9. Secondly, as local secretion of cytokines is a feature of chronic inflammation induced by $H$ pylori, ${ }^{20}$ we postulated that this might be a factor in expression of CD44 variants.

\section{Methods}

PATIENTS AND GASTRIC BIOPSY SPECIMENS Group I comprised 18 patients (seven men 
and 11 women; mean age $47 \cdot 2$ years; range 21-78 years) attending for endoscopy due to symptoms from the upper gastrointestinal tract were included. Ten of them were $H$ pylori positive (including four patients who had duodenal ulcer) and eight were $H$ pylori negative (three patients with chronic inflammation and five patients with normal gastric mucosa).

Group II comprised an additional 10 patients (five men and five women) who were analysed for CD44 variant expression. In five patients, gastritis and duodenal ulcer were diagnosed endoscopically and histologically. Five patients were $H$ pylori negative and had normal gastric mucosa.

Biopsy specimens were taken during upper gastrointestinal endoscopy from the gastric antrum. $H$ pylori was identified histologically by haematoxylin and eosin, Giemsa staining, and CLO test.

\section{SEPARATION OF THE GASTRIC EPITHELIAL} CELLS AND INTRAEPITHELIAL LYMPHOCYTES Gastric epithelial cells (EP) and intraepithelial lymphocytes (IEL) were separated by a modification of a previously described technique. ${ }^{21}$ Four gastric biopsy specimens were placed in Hanks' balanced salt solution without calcium and magnesium (CMF HBSS Gibco, $+5 \%$ fetal calf serum (FCS)) containing $1 \mathrm{mM}$ dithiothreitol (DTT, Sigma) and 1 mM EDTA (Analar^, BDH Chemicals Ltd, Poole, England) in a $20 \mathrm{ml}$ universal V-bottomed container (Bibby Sterilin Ltd, Staffs, UK). The container was then allowed to tumble freely in a basket attached to a rotating blood mixer (Matburn Blood Cell Suspension Mixer) for one hour at $37^{\circ} \mathrm{C}$. The specimens were then washed twice with RPMI 1640 (Gibco) containing 10\% FCS. The number and viability $(>90 \%)$ of IEL and EP were determined using ethidium bromide/acridine orange (EB/AO). Viability of IEL and EP was consistently greater than $90 \%$. The yield of viable IEL ranged from $0 \cdot 55-7 \cdot 2 \times 10^{7} / \mathrm{ml}$ and the yield of viable EP ranged from $3 \cdot 2-17 \cdot 8 \times 10^{7} / \mathrm{ml}$. In preliminary studies, ${ }^{22}$ the specimens were examined histologically after the isolation procedure to ensure integrity of the basement membrane and of the lamina propria. Integrity was maintained for up to two hours incubation in DTT/EDTA. In the experiments described here, a one hour incubation was used with adequate removal of the epithelial layer alone.

\section{FLOW CYTOMETRIC ANALYSIS}

Preparation of the cells

The IEL and EP were resuspended in phosphate buffered saline (PBS) containing bovine serum albumin (BSA, $1 \%, \mathrm{v} / \mathrm{v}$ ) and sodium azide $(0.02 \%$, w/v). The cells $\left(1 \times 10^{5}\right)$ were dispensed in $100 \mu l$ aliquots to the appropriate tubes, washed twice with PBS/BSA/azide, and centrifuged at $250 \mathrm{~g}$ for three minutes at $4^{\circ} \mathrm{C}$.
Two colour immunofluorescence analysis of cell surface molecules

Specific antibodies included anti-CD44 (5 $\mu$, L3D1, a kind gift of Dr M B Omary), D.2.1, ( ${ }^{23}$ and unpublished observation), anti-CD44 variants (v6 and v9) (Bender MedSystems), anti-HLA-DR (a kind gift of Dr Peter Lydyard, Middlesex Hospital), anti-HLA-DP, and anti-HLA-DQ (Becton Dickinson) (all IgG antibodies). An anti-murine major histocombatibility complex (MHC) antibody (antiIE) (IgG) was used as an isotype control for all adhesion molecule antibodies and HLA class II antibodies.

The procedure was as follows. Specific antibody was added to the appropriate tubes; anti-IE $(10 \mu \mathrm{l})$ was added to the control tube. The tubes were incubated at room temperature for 15 minutes, then washed with PBS/BSA/azide $(\times 2)$. FITC conjugated $\mathrm{F}\left(\mathrm{ab}^{1}\right)_{2}$ fragments of rabbit anti-mouse immunoglobulin $(1: 100,100 \mu \mathrm{l})$ were added to each tube and incubated at room temperature for 10 minutes. The cells were again washed with PBS/BSA/azide $(\times 2)$. Normal mouse serum $(1: 50,50 \mu \mathrm{l})$ was added to each tube to block non-specific binding sites and the tubes were incubated at room temperature for 10 minutes followed by two washes with PBS/BSA/azide. Before staining with antiCD44 variant (v6), the cells were prefixed with $2 \%$ paraformaldehyde in PBS $(0.5 \mathrm{ml})$ for 10 minutes.

Phycoerythrin conjugated anti-CD3 (CD3 PE) $(5 \mu \mathrm{l})$ was added to each of the above tubes and incubated for 10 minutes followed by washing with $\mathrm{PBS} / \mathrm{BSA} / \mathrm{azide}(\times 2)$. The cells were then fixed with $0.5 \%$ paraformaldehyde in PBS $(0.5 \mathrm{ml})$ and analysed using the Becton Dickinson FACScan and Lysys software. Histological examination of sections showed that one hour incubation removed only the epithelial layer leaving the basement membrane intact suggesting that we had a pure single cell suspension derived from the epithelial layer. Hence, $\mathrm{CD} 3$ negative cells were classified as epithelial cells. ${ }^{22}$ The mean fluorescence intensity and percentage of positive cells were estimated from the gate accumulated histograms.

STUDIES ON CULTURED GASTRIC EPITHELIAL CELL LINE (AGS)

(1) Activated PBMC supernatant was prepared by co-culturing PBMC from a healthy volunteer ( $H$ pylori negative) at a concentration of $2 \times 10^{6} / \mathrm{ml}$ for 24 hours with anti-CD3 (OKT3) in RPMI medium. After 24 hours' stimulation, lymphocytes were washed three times and incubated for a further 24 hours in the medium. Medium at the end of this period was collected and used as activated PBMC supernatant. ${ }^{24}$

(2) A gastric epithelial cell line, AGS (ATCC), derived from a human gastric adenocarcinoma was cultured in the flasks at $37^{\circ} \mathrm{C}$ in a humidified atmosphere of $5 \% \mathrm{CO}_{2}$ in air. When the AGS cells were grown to subconfluency, they were incubated for a further 24 hours with 

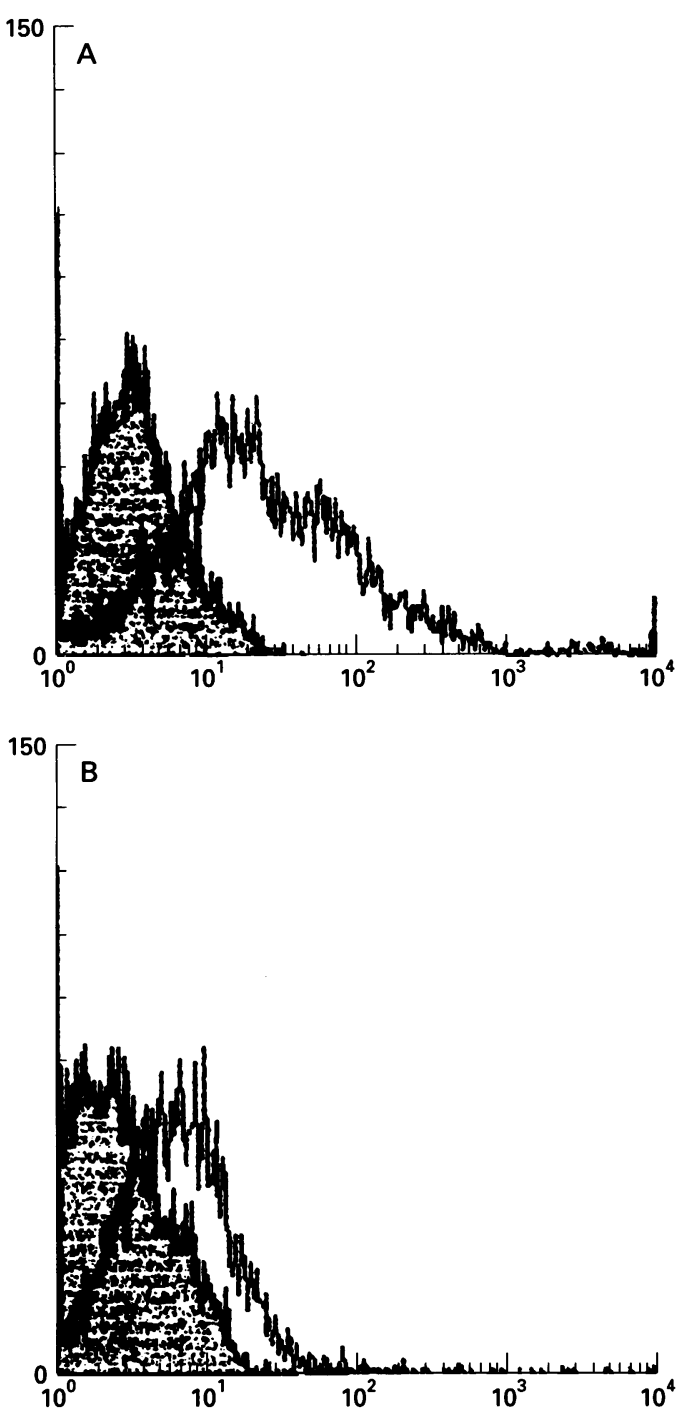

Figure 1: FACScan profiles of CD44 (L3D1 antibody) expression on gastric epithelial cells in Helicobacter pylori positive $(A)$ and negative $(B)$ patients. The shaded peaks represent fluorescence when the epithelial cells are incubated with FITC-labelled isotype control (anti-IE). The unshaded peaks represent staining with FITC-labelled anti-CD44 on CD3 negative cells (epithelial cells).

medium alone, recombinant tumour necrosis factor $\alpha$ (TNF- $\alpha$, gift of Cetus corporation Emeryville, CA, USA, $6 \mathrm{ng} / \mathrm{ml})$ and IFN- $\gamma(5$ $\mathrm{ng} / \mathrm{ml}$; kindly donated by Dr Kingston Mills, National Institute for Biological Standards, UK), and activated PBMC supernatant. ${ }^{24}$ After co-culture with different cytokines and activated PBMC supernatant, the cells were removed from flasks by $0.05 \%(w / v)$ EDTA treatment,

TABLE I Expression of CD44 in gastric epithelial cells (EP) and intraepithelial lymphocytes (IEL) using two separate monoclonal antibodies $D 2.1$ and L3D1. Flow cytometric analysis is described in the methods section. The data are presented as mean (SEM) fluorescence intensity. D 2.1 has a higher affinity and gives consistently higher readings than $L 3 D 1$

\begin{tabular}{|c|c|c|}
\hline & \multicolumn{2}{|c|}{ Fluorescence intensity (mean (SEM)) } \\
\hline & $D 2.1$ & $L 3 D 1$ \\
\hline $\begin{array}{l}\text { EP }(H P+v e)(n=10) \\
\text { EP (HP-ve) }(n=5) \\
\text { EP (HP-ve) with chronic inflammation }(n=3) \\
\text { p }\end{array}$ & $\begin{array}{l}180.9(25 \cdot 5)^{\star} \\
89 \cdot 82(18 \cdot 8) \\
96 \cdot 25(20 \cdot 8) \\
<0.02\end{array}$ & $\begin{array}{r}153.9(48.2)^{\star} \\
28.66(13.6) \\
33.08(17.8) \\
<0.02\end{array}$ \\
\hline $\begin{array}{l}\text { IEL }(H P+v e)(n=10) \\
\text { IEL }(H P-v e)(n=5) \\
\text { IEL (HP-ve) with chronic inflammation }(n=3) \\
p\end{array}$ & $\begin{array}{l}167 \cdot 0(34 \cdot 4) \\
145 \cdot 5(19 \cdot 4) \\
126 \cdot 7(22 \cdot 7) \\
\text { NS }\end{array}$ & $\begin{array}{l}215 \cdot 6(50 \cdot 1) \\
178 \cdot 3(35 \cdot 7) \\
186 \cdot 4(46 \cdot 8) \\
\text { NS }\end{array}$ \\
\hline
\end{tabular}

$\mathrm{HP}=$ Helicobacter pylori resuspended in fresh medium, and labelled using the monoclonal antibodies anti-CD44 (L3D1 and D.2.1), anti-CD44 (v6), and (v9).

\section{STATISTICAL ANALYSIS}

The significance of the difference between the $H$ pylori positive and negative groups was evaluated using the Student's $t$ test and the Mann-Whitney U test. Data were expressed as mean (SEM). Results were expressed as the mean fluorescence intensity of cells, when most cells expressed a particular marker. Results were expressed as the percentage of cells stained with the specific monoclonal antibody above the percentage of the same cells stained with the control when only a small minority expressed the marker.

\section{Results}

CD44 AND ITS VARIANTS (v6, v9) EXPRESSION ON GASTRIC EPITHELIAL CELIS

EP and IEL expressed the adhesion molecule CD44 as assessed using two separate monoclonal antibodies (L3D1, D2.1). A FACScan profile of adhesion molecule CD44 (L3D1 antibody) expression on EP is shown in Figure 1. Expression of CD44 (L3D1, D2.1) was significantly increased $(p<0.02)$ on EP in $H$ pylori positive compared with $H$ pylori negative individuals with or without chronic inflammation (Table I). There were no statistically significant differences in expression of CD44 (L3D1, D2.1) on gastric intraepithelial lymphocytes between the $H$ pylori positive and negative groups (Table I).

In addition, the CD44 variant (v9) was not expressed on $H$ pylori negative EP cells and was detected to varying degrees on $H$ pylori positive EP. A FACScan profile of adhesion molecule CD44 v9 expression on EP is shown in Figure 2. There was a significantly increased $(\mathrm{p}<0.05)$ expression of CD44 v9 on EP from patients with $H$ pylori infection compared with uninfected patients (Table II). CD44 v6 expression by contrast was detected even in normal gastric mucosa. While levels of CD44 v6 were increased in $H$ pylori positive individuals this did not reach statistical significance in this study (Table II).

HLA-DR, HLA-DP, AND HIA-DQ EXPRESSION ON EP AND IEL

Surface HLA-DR, HLA-DP, and HLA-DQ were examined on EP and IEL by two colour immunofluorescence staining. The results showed significantly higher $(p<0.05)$ HLADR and HLA-DP expression on EP of patients with $H$ pylori infection than in uninfected individuals with or without chronic inflammation (Table III).

Fluorescence labelling of gastric IEL also showed strong HLA-DR $(p<0 \cdot 005)$ and HLADP $(p<0.02)$ expression of $H$ pylori positive patients compared with $H$ pylori negative patients with or without chronic inflammation (Table III). 

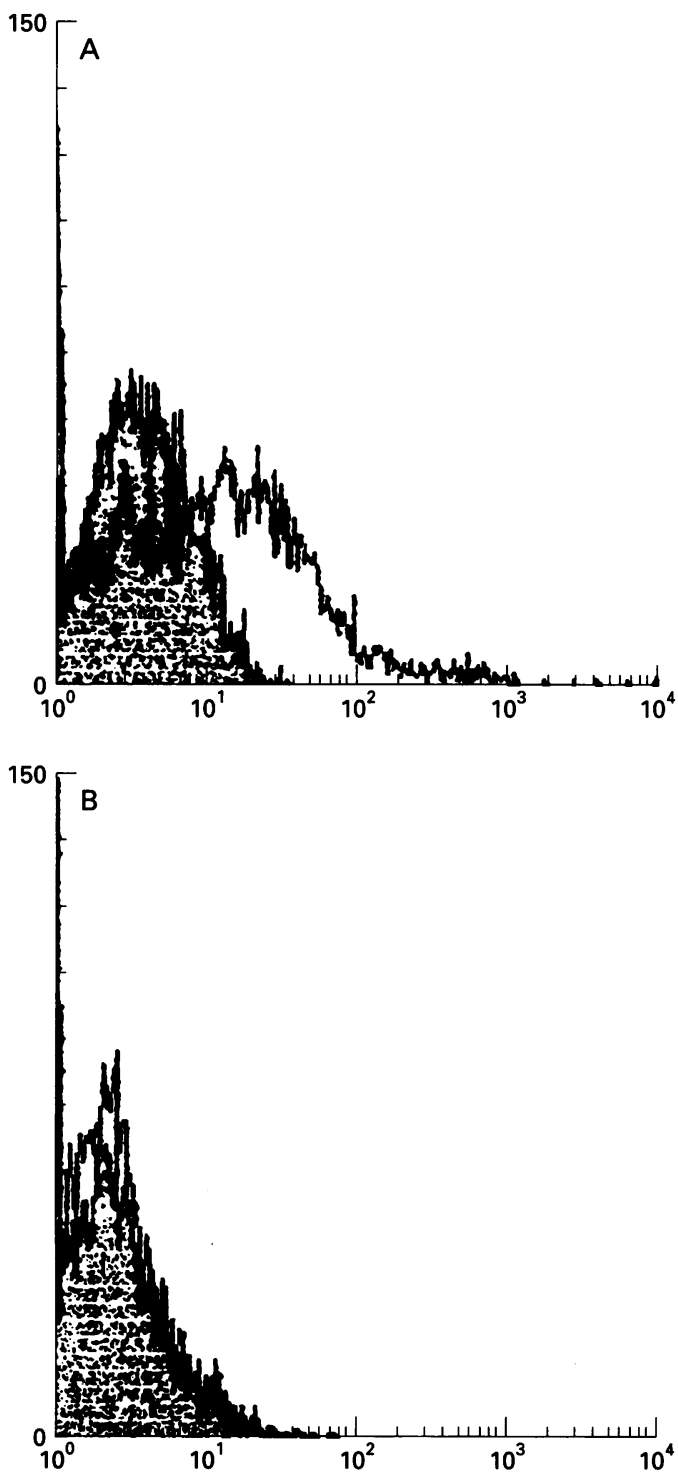

Figure 2: FACScan profiles of $v 9$ expression on gastric epithelial cells in Helicobacter pylori positive $(A)$ and negative (B) patients. The shaded peaks represent fluorescence when the epithelial cells are incubated with FITC-labelled isotype control (anti-IE). The unshaded peaks represent staining with FITC-labelled anti-CD44 (v9) on CD3 negative cells (epithelial cells).

However, there was no statistically significant difference in HLA-DQ expression in either EP or IEL in $H$ pylori positive and negative groups (Table III).

CYTOKINE UPREGULATION OF CD44

EXPRESSION ON AGS

CD44 expression on the AGS cell line was examined after their incubation with different cytokines and activated PBMC supernatant. CD44 expression was significantly upregulated

TABLE II Expression of CD44 variants $(v 6, v 9)$ on gastric epithelial cells (EP). Flow cytometric analysis is described in the methods section. The data are presented as mean (SEM) fluorescence intensity

\begin{tabular}{lll}
\hline & \multicolumn{2}{l}{ Fluorescence intensity $($ mean $($ SEM)) } \\
\cline { 2 - 3 } & CD44 variant (v6) & CD44 variant (v9) \\
\hline EP (HP+ve) (n=5) & $120 \cdot 1(30 \cdot 8)$ & $27.33(7 \cdot 5)^{\star}$ \\
EP (HP-ve) $(n=5)$ & $62 \cdot 08(7.61)$ & $13.93(1.56)$ \\
p & NS & $<0.05$ \\
\hline
\end{tabular}

by the activated PBMC supernatant. Further analysis has shown that both IFN- $\gamma$ and TNF- $\alpha$ significantly increased CD44 expression (Fig 3). However, neither the crude supernatant nor recombinant cytokines IFN- $\gamma$ and TNF- $\alpha$ had any significant effect on expression of CD44 v6 or v9 on AGS cells (Fig 3).

\section{Discussion}

In this study we have shown increased expression of CD44 and CD44 v9 in H pylori infected gastric antral mucosa compared with normal gastric mucosa using flow cytometry. CD44 and its variants have been previously detected by immunohistochemistry in gastric EP in a number of studies. ${ }^{12} 25$ Flow cytometry is a more sensitive technique than immunohistochemistry for detection of expression of surface molecules and additionally allows quantitative analysis. We found that CD44 v9 was not expressed in $H$ pylori negative gastric EP and was detected to varying degrees in $H$ pylori positive gastric EP. By contrast, however, CD44 v6 expression was detected even in normal gastric mucosa. Our results are consistent with results obtained by immunohistochemistry by Fox et al, ${ }^{12}$ who reported that CD44 v6 but not v9 was expressed on normal human gastric and duodenal tissues.

The mechanism by which $H$ pylori regulates CD44 expression is unknown. Since $H$ pylori binds to gastric EP, CD44 expression may be a direct cellular response to products of $H$ pylori. Upregulation of CD44 and CD44 variants is found in other conditions characterised by chronic inflammation such as ulcerative colitis. ${ }^{2627}$ IFN- $\gamma$ has been shown to induce CD44 expression in myelomonocytic cell lines and TNF- $\alpha$ has been shown to increase $\mathrm{v} 9$ expression in $\mathrm{T}$ cells and endothelial cells. ${ }^{102929}$ Hence, we examined HLA class II expression on gastric EP and IEL as a marker of a functional effect of IFN- $\gamma$ secretion. We found that HLA-DR and DP expression were increased in gastric EP and IEL in patients with $H$ pylori associated antral gastritis and peptic ulcer. This finding has been noted by others and is not surprising since an immune response to foreign bacterial antigens would be expected to lead to $\mathrm{T}$ cell activation and the release of IFN- $\gamma$ and other cytokines. $^{30} 31$ IFN- $\gamma$ and TNF- $\alpha$ are produced locally in gastric mucosa. Production of TNF- $\alpha$ and IFN- $\gamma$ was found to be increased in gastric mucosa in $H$ pylori positive individuals. ${ }^{32} 33$ In contrast to HLA class II, we did not find an increase in CD44 expression on gastric IEL. This suggests that other factors in addition to IFN- $\gamma$ (possibly TNF- $\alpha$ ) may be needed for CD44 expression in IEL, and probably also in other cells such as gastric EP.

The data obtained for the gastric EP line (AGS) show upregulation of CD44 but not CD44 variant v6 and v9 expression when stimulated by TNF- $\alpha$, IFN- $\gamma$, and activated PBMC supernatant. These data suggest that factors related to $H$ pylori infection, but not produced by activated mononuclear cells, may 
TABLE III Expression of HLA-DR, HLA-DP, and HLA-DQ on gastric epithelial cells (EP) and intraepithelial lymphocytes (IEL). The cell labelling is measured as described in the methods section. The data is presented as percentage of positive cells

\begin{tabular}{|c|c|c|c|}
\hline & \multicolumn{3}{|c|}{$\%$ Positive cells (mean (SEM)) } \\
\hline & $H L A-D R$ & $H L A-D P$ & $H L A-D Q$ \\
\hline $\begin{array}{l}\mathrm{EP}(\mathrm{HP}+\mathrm{ve})(\mathrm{n}=10) \\
\mathrm{EP}(\mathrm{HP}-\mathrm{ve})(\mathrm{n}=5) \\
\mathrm{EP}(\mathrm{HP}-\mathrm{ve}) \text { with chronic inflammation }(\mathrm{n}=3) \\
\mathrm{p}\end{array}$ & $\begin{array}{r}12.5(4 \cdot 1)^{\star} \\
3.60(1 \cdot 4) \\
4 \cdot 20(2 \cdot 1) \\
<0.05\end{array}$ & $\begin{aligned} 10.0(2 \cdot 8)^{\star} \\
2.50(0.6) \\
2.58(1.1) \\
<0.05\end{aligned}$ & $\begin{array}{l}5 \cdot 7(2 \cdot 2) \\
2 \cdot 2(1 \cdot 2) \\
4 \cdot 5(2 \cdot 5) \\
\text { NS }\end{array}$ \\
\hline $\begin{array}{l}\text { IEL }(H P+v e)(n=10) \\
\text { IEL }(H P-v e)(n=5) \\
\text { IEL }(H P-v e) \text { with chronic inflammation }(n=3) \\
p\end{array}$ & $\begin{array}{l}14.3(3.9)^{\star} \\
3.99(0.9) \\
4.29(0.7) \\
<0.005\end{array}$ & $\begin{array}{l}19 \cdot 1(4 \cdot 7)^{\star} \\
7 \cdot 1(1 \cdot 2) \\
5 \cdot 38(2 \cdot 5) \\
<0 \cdot 02\end{array}$ & $\begin{array}{l}4 \cdot 1(1 \cdot 6) \\
2 \cdot 6(0 \cdot 8) \\
3 \cdot 6(1 \cdot 3) \\
\text { NS }\end{array}$ \\
\hline
\end{tabular}

be involved in the expression of CD44 variants. Mediators produced by other cells such as EP, fibroblasts and other stromal cells may be required for this effect. While the degree of CD44 induction by supernatant in in vitro studies was not equivalent to that seen in vivo. This may suggest that combinations of cytokines from both immune and non-immune source may be necessary for maximal induction of CD44. Furthermore, we can not exclude the possibility that $H$ pylori proteins in concert with cytokines may contribute to increased CD44 expression. Gastric cancer associated with $H$ pylori arises out of areas of multifocal atrophic gastritis with intestinal metaplasia. Hence a local inflammatory response to the organism could alter expression of CD44.

$H$ pylori induced CD44 expression on gastric EP may be important in both normal EP function and in the pathogenesis of gastric cancer. CD44 is thought to be functionally involved in adherence of cells to the extracellular matrix molecules including hyaluronic acid fibronectin and collagen. ${ }^{10}$ In animal models of metastasis, blocking antibodies to CD44 variants inhibit metastases formation. ${ }^{34} 35$ Transfection of CD44 variant

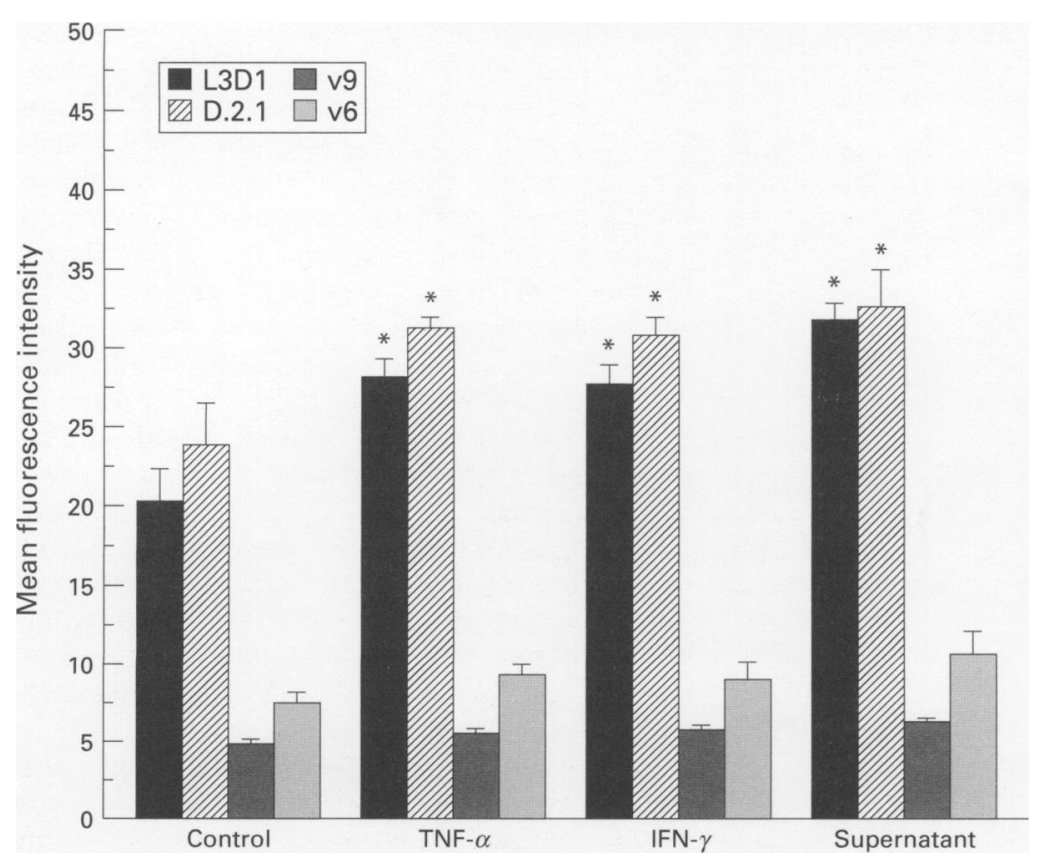

Figure 3: Comparison of CD44 and its variants $(v 9, v 6)$ expression on the AGS cell line between control and tumour necrosis factor $\alpha$, interferon $\gamma$, and activated peripheral blood mononuclear cells supernatant stimulated groups. AGS labelling is described in the methods section. The data are presented as mean fluorescence intensity. $n=6$ Determinants for each group. ${ }^{\star} p<0.05$ compared with control.
cDNA converts non-metastatic carcinoma and sarcoma cells into metastatic cells in the rat. ${ }^{36}$ Variant forms of CD44 differ in their binding affinity towards extracellular matrix ligands and this property could contribute to the metastatic potential of cells expressing CD44 variants. ${ }^{37}$ In addition, CD44 ligand binding on tumour cells may also play a direct role in cell proliferation. ${ }^{35}$ Hence, $H$ pylori induced upregulation of CD44 and expression of variant exons could not only play a role in regulation of epithelial cell proliferation in the gastric mucosa but also in the metastatic potential of $H$ pylori associated tumours.

In conclusion, we have shown that $H$ pylori infection of the gastric mucosa is associated with increased expression of CD44 and its variant (v9) on gastric epithelial cells. Furthermore, we have shown upregulation of CD44 expressed on AGS by TNF- $\alpha$, IFN- $\gamma$, and activated PBMC supernatant. $H$ pylori, either directly or indirectly, may be at least partly responsible for the increased expression of CD44 and its variant v9 in gastric carcinomas.

DK is a Wellcome Senior Fellow in Clinical Science. Aideen Long was supported by the Cancer Research Advancement Board of the Irish Cancer Society.

1 Marshall BJ, Warren JR. Unidentified curved bacilli in the stomach of patients with gastritis and peptic ulceration. Lancet 1984; i: 1311-5.

2 Nomura A, Stemmerman GN, Chyou P-H, Kato I, PérezPérez GI, Blaser MJ. Helicobacter pylori infection and gastric carcinoma among Japanese Americans in Hawaii. N Engl f Med 1991; 325: 1132-6.

3 Parsonnet J, Friedman GD, Vandersteen DP, Chang Y, Vogelman JH, Orentreich $\mathrm{N}$. Helicobacter pylori infection and the risk of gastric carcinoma. $N$ Engl $f$ Med 1992; 325: $1127-31$.

4 O'Connor HJ. Helicobacter pylori and gastric cancer - a view and hypothesis. Eur $\mathcal{f}$ Gastroenterol Hepatol 1992; 4: view $1-7$.

5 Axon ATR, Lynch DAF. Helicobacter pylori, gastric physiology and cancer. Eur $f$ Gastroenterol Hepatol 1993; 5 (suppl 1): S109-13

6 Sakaki N, Momma K, Yamada Y, Tajima T, Shoji F, Handa N, Takizawa T. Helicobacter pylori and early gastric cancer: relation to atrophic gastritis in background gastric mucosa. Eur $\mathcal{F}$ Gastroenterol Hepatol 1993; 5 (suppl 1): S123-6.

7 Cahill RJ, Sant S, Beattie S, Hamilton H, O'Morain C. Helicobacter pylori and increased epithelial cell proliferation: a risk factor for cancer. Eur $\mathcal{\exists}$ Gastroenterol Hepatol tion: a risk factor

8 Fan XG, Kelleher D, Fan XJ, Xia HX, Keeling PWN. Direct and indirect effects of $\mathrm{H}$ pylori on cell cycle of gastric epithelial cell line AGS. Ir $\mathcal{F}$ Med Sci 1994; 163 297.

9 Haynes BF, Telen MJ, Hale LP, Denning SM. CD44: a molecule involved in leukocyte adherence and $\mathrm{T}$ cell activation. Immunol Today 1989; 10: 423-8.

10 Miyake K, Underhill CB, Lesley J, Kincade PW. Hyaluronate can function as a cell adhesion molecule and CD44 participates in hyaluronate recognition. 7 Exp Med 1990; 172: 69-75.

11 Mackay CR, Terpe HJ, Stauder R, Marston WL, Stark JH, Gunthert $U$. Expression and modulation of CD44 variant isoforms in humans. $\mathcal{F}$ Cell Biol 1994; 124: 71-82.

12 Fox SB, Fawcett J, Jackson DG, Collins I, Gatter KC Harris AL, et al. Normal human tissues, in addition to some tumors, express multiple different CD44 isoforms. Some tumors, express multiple

13 Hughes EN, Mengod G, August JT. Murine cell surface glycoproteins. Characterization of a major components of 80000 daltons as a polymorphic differentiation antigen of mesenchyma cells. $\mathcal{f}$ Biol Chem 1981; 256: 7023-7.

14 Brown TA, Bouchard T, St John T, Wayner E, Carter WG Human keratinocytes express a new CD44 core protein (CD44E) as a heparin sulfate intrinsic membrane proteoglycan with additional exons. F Cell Biol 1991; 113: 207-21.

15 Galandrini R, Albi N, Tripodi G, Zarcone D, Terenzi A, Moretta A, et al. Antibodies to CD44 trigger effector functions of human $\mathrm{T}$ cell clones. F Immunol 1993; 150: 4225-35.

16 Horst E, Meijer CILM, Radaszkiewicz T, Ossekoppele GJ, van Krieken JHJM, Pals ST. Adhesion molecules in the 
prognosis of diffuse large cell lymphoma: expression of a lymphocyte homing receptor (CD44), LFA-1 (CD11a/18) and ICAM-1 (CD54). Leukemia 1990; 4: 595-99.

17 Joensuu H, Ristamaki R, Klemi PJ, Jalkanen S. Lymphocyte homing receptor (CD44) expression is associated with poor prognosis in gastrointestinal lymphoma. $\mathrm{Br} \mathcal{F}$ Cancer 1993 ; 68: 428-32.

18 Joensuu $H$, Klemi PJ, Toikkanen $S$, Jalkanen $S$. Glycoprotein CD44 expression and its association with survival in breast cancer. Am $\mathcal{F}$ Pathol 1993; 143: 867-74.

19 Tanabe KK, Ellis LM, Saya H. Expression of CD44R1 adhesion molecule in colon carcinomas and metastases. Lancet 1993; 341: 725-6.

20 Ernst PB, Jin Y, Reyes VE, Crowe SE. The role of the local immune response in the pathogenesis of peptic ulcer formation. Scand f Gastroenterol 1994; 29 (suppl 205): 22-8.

21 Madrigal L, Lynch S, Feighery C, Weir D, Kelleher D, O'Farrelly C. Flow cytometric analysis of surface major O'Farrelly C. Flow cytometric analysis of surface major histocompatibility complex class II expression on human epithelial cells prepared from small inte

22 Fan XJ, Long A, Fan XG, Keeling PWN, Kelleher D. Adhesion molecule expression on gastric intraepithelial lymphocytes of patients with Helicobacter pylori infection. Eur $\mathcal{F}$ Gastroenterol Hepatol 1995; 7: 541-6.

23 Kelleher D, Murphy A, Lynch S, O'Farrelly C. Adhesion molecules utilised in binding of intraepithelial lymphocytes to human enterocytes. Eur $\mathcal{F}$ Immunol 1994; 24: 1013-6.

24 Fan CG, Kelleher D, Fan XJ, Xia HX, Keeling PWN. Helicobacter pylori increases proliferation of gastric epithelial cells. Gut 1996; 38: 19-23.

25 Mayer B, Jauch KW, Günthert U, Figdor CG, Schildberg FW, Funke L, et al. De-novo expression of CD44 and surFW, Funke L, et al. De-novo expression of CD44
vival in gastric cancer. Lancet 1993; 342: 1019-22.

26 Haynes BF, Hale LP, Patton KL, Martin ME, McCallum RM. Measurement of an adhesion molecule as an indicator of inflammatory disease activity: up-regulation of the receptor for hyaluronate (CD44) in rheumatoid arthritis. Arthritis Rheum 1991; 34: 1434-43.

27 Rosenberg WMC, Prince C, Kaklamanis L, Fox SB, Jackson DG, Simmons DL, et al. Increased expression of
CD44v6 and CD44v3 in ulcerative colitis but not colonic Crohn's disease. Lancet 1995; 345: 1205-9.

8 Mackay F, Loetscher H, Stueber D, Gehr G, Lasslauer W. Tumour necrosis factor alpha (TNF-alpha)-induced cell adhesion to human endothelial cells is under dominant control of one TNF receptor type, TNF-R55. $\mathcal{f}$ Cell Biol control of one TN

29 Sallusto F, Lanzavecchia A. Efficient presentation of soluble antigen by cultured human dendritic cells is maintained by granulocyte/macrophage colony stimulating factor plus interleukin 4 and downregulated by tumour necrosis factor alpha. $\mathcal{F} \operatorname{Exp} M e d$ 1994; 179: 1109-18.

30 Wee A, Teh M, Kang JY. Association of Helicobacter pylori with HLA-DR antigen expression in gastritis. $\mathcal{F}$ Clin Pathol 1992; 45: 30-3.

31 Spencer J, Finn T, Isaacson PG. Expression of HLA-DR antigens on epithelium associated with lymphoid tissue in the human gastrointestinal tract. Gut 1986; 27: in the

32 Fan XJ, Chau A, O'Connell MA, Kelleher D, Keeling PW. Interferon-gamma and tumour necrosis factor production in patients with Helicobacter pylori infection. Ir f Med Sci 1993; 162: 408-11.

33 Crabtree JE, Shallcross TM, Heatley RV, Wyatt JI. Mucosa tumour necrosis factor $\alpha$ and interleukin- 6 in patients with Helicobacter pylori associated gastritis. Gut 1991; 32: 1473-77.

34 Seiter S, Arch R, Reber S, Komitowski D, Hofmann M, Ponta H, Herrlich P, Matzku S, Zoller M. Prevention of tumor metastasis formation by anti-variant CD44. f Exp Med 1993; 177: 443-55.

35 Guo Y, Ma J, Wang J, Che X, Narula J, Bigby M, Wu M, Sy MS. Inhibition of human melanoma growth and metaMS. Inhibition of human melanoma growth and metaRes 1994; 54: 1561-5.

36 Günthert U, Hofmann M, Rudy W, Reber S, Zoller M, Haussmann I, Matzku S, et al. A new variant of glycoprotein CD44 confers metastatic potential to rat carcinoma cells. Cell 1991; 65: 13-24.

37 Dougherty GJ, Cooper DL, Memory JF, Chiu RK. Ligand binding specificity of alternatively spliced CD44 isoforms. Recognition and binding of hyaluron by CD44R1. $\mathcal{F}$ Biol Chem 1994; 269: 9074-8. 